\title{
The development of coffee cultivation in the traditional agroforestry of mixed-garden (dukuh lembur) to provide social-economic benefit for the Outer Baduy Community, South Banten, Indonesia
}

\author{
BUDIWATI S. ISKANDAR ${ }^{1}$, JOHAN ISKANDAR ${ }^{2}$, BUDI IRAWAN ${ }^{2}$, SUROSO $^{3}$, RUHYAT PARTASASMITA ${ }^{2, \bullet}$ \\ ${ }^{1}$ Department of Anthropology, Faculty of Social and Political Science, Universitas Padjadjaran. Jl. Raya Bandung-Sumedang Km 21, Kampus Jatinangor, \\ Sumedang 45363, West Java, Indonesia \\ ${ }^{2}$ Department of Biology, Faculty of Mathematics and Natural Sciences, Universitas Padjadjaran. Jl. Raya Bandung-Sumedang Km 21, Jatinangor, \\ Sumedang 45363, West Java, Indonesia. Tel.: +62-22-7797712. `email: rp2010rikkyo@gmail.com; ruhyat.partasasmita@unpad.ac.id \\ ${ }^{3}$ Program of Biology, Faculty of Mathematics and Natural Sciences, Universitas Padjadjaran, Kampus Jatinangor, Sumedang 45363, West Java. \\ Indonesia
}

Manuscript received: 17 August 2019. Revision accepted: 16 September 2019.

\begin{abstract}
Iskandar BS, Iskandar J, Irawan I, Suroso, Partasasmita R. 2019. The development of coffee cultivation in the traditional agroforestry of mixed-garden (dukuh lembur) to provide social-economic benefit for the Outer Baduy Community, South Banten, Indonesia. Biodiversitas 20: 2958-2969. The Baduy community who resides in the Village of Kanekes, the Sub-district of Leuwidamar, the District of Lebak, South Banten has maintained the Sundanese tradition, particularly in practicing swidden farming (ngahuma). They practice swidden farming based on Traditional Ecological Knowledge (TEK) and belief. According to the Baduy tradition, the commercial plants, including coffee, clove, cacao, teak, and rubber have been prohibited to cultivate in Baduy area. However, because the population has increased rapidly and market economy has intensively penetrated the Baduy area, some commercial plants, including robusta coffee (Coffea canephora Pierre ex A. Froehner) have been introduced by the outer Baduy community. The objective of this study was to elucidate the traditional practice of the Outer Baduy in cultivating coffee trees that are integrated into the traditional agroforestry of mixed-garden (dukuh lembur or leuweung lembur). This study used qualitative method with some techniques of collecting data, including observation, participant observation, semi-structured interviews, and plant survey in the sample plots of the dukuh lembur. The results of the study showed that in 1980-s the robusta coffee plants were introduced by some Outer Baduy people and have since been planted in the dukuh lembur. In the past, because coffee was prohibited to be cultivated in Baduy area, the coffee trees were regularly cut during the purification of the Baduy tradition (pembersihan adat). Nowadays, however, the robusta coffee trees have been properly integrated into the existing dukuh lembur which is based on hybrid knowledge of TEK and scientific Western knowledge. The Outer Baduy coffee farming system has provided subsistence as a well commercial economy that may support the sustainability of the Outer Baduy swidden cultivation that is considered as the cultural identity of the Baduy community.
\end{abstract}

Keywords: Coffee cultivation, huma system, Outer Baduy, traditional agroforestry

\section{INTRODUCTION}

The Baduy community who resides in the Village of Kanekes, the Sub-district of Leuwidamar, the District of Lebak, southern of Banten Province, Indonesia has been widely recognized as one of the traditional Sundanese communities who is still maintaining the Sundanese tradition, particularly in practicing swidden farming (ngahuma). The Baduy people manage their swidden farming system strongly based on Traditional Ecological Knowledge (TEK) and belief (cf. Iskandar 1998). The TEK or folk knowledge may be defined as a cumulative body of knowledge, practice, and belief, evolving by adaptive processes that is normally gathered over generations by observers whose lives depended on this information and its use. It often accumulates incrementally, tested by trial-anderror and transmitted to future generations orally or by shared practical experiences (Berkes et al. 2000; Ellen and Harris 2000; Berkes 2008; Orlove et al. 2010).

For the Baduy community, the practice of swidden farming has played an important role not only for economic purpose but also to fulfill an obligation of their religion, Sunda Wiwitan or Agama Baduy. Various TEK, including the Baduy calendar or Pananggalan Baduy, has been intensively applied by the Baduy community to manage the annual swidden cultivation system. In addition, they believe that rice has a Goddess called Nyi Pohaci (Dewi Sri in Javanese). Consequently, the timing of each stage of the rice planting of the Baduy swidden cultivation is based on the guideline of the traditional Baduy calendar, and integrated with various traditional rituals (Iskandar 1998; Iskandar and Ellen 1999; Iskandar and Iskandar 2017; Iskandar and Iskandar 2018). Therefore, both the traditional Baduy calendar and traditional ritual play a vital role as an institutional instrument, designed to generate collective actions from members of the Baduy community in the swidden farming (cf. Franco 2015). In addition, the belief system has served a variety of adaptive management tools for the Baduy community and their members to manage their local environment. According to the Baduy traditions, hoeing soil, using the modern new rice varieties, 
applying inorganic fertilizers, and synthetic pesticides have been prohibited in practicing swidden farming.

The rice of swidden system (pare huma) is prohibited to sell because their believe that Nyi Pohaci will be offended if the swidden rice is sold. Accordingly, the swidden rice (pare huma) production is usually stored in the rice barns (leuit) for some decades and can be inherited by their children. The swidden rice has been mainly used for performing various traditional rituals and home consumption, particularly if the Baduy household does not have enough money to buy rice of sawah from village small shops (warung). In addition, some commercial crops or plants, including clove, coffee, para rubber, and teak that are considered as new crops and come from outsiders have been prohibited (tabu or teu wasa) to cultivate in Baduy area. As a result, according to historical ecology, those commercial plants have not been introduced and cultivated in Baduy area (Iskandar 1998).

Because of the population increase, the forest and swidden field decrease, and intensive market economy penetration to Baduy area, various strategies have been undertaken by the Outer Baduy community to maintain the sustainability of the traditional swidden farming system. For example, they have been conducting temporary migration to the neighboring non-Baduy area to practice swidden farming, to get involved in petty trading on nonrice crop productions, to work as laborers, such as carrying albizia logs, weeding garden, and harvesting rice, and to introduce commercial crops, such as albizia, clove, cacao, and coffee (Iskandar 2007; Iskandar and Ellen 2007; Iskandar et al. 2018a).

The albizia trees (Paraserianthes falcataria L. Nielsen) have been introduced and properly integrated into the swidden farming system of the Outer Baduy since 1980 (Iskandar and Ellen 2000, 2007). The albizia trees have provided some ecological and socio-economic benefits, including improving soil fertility, providing firewood, and providing cash income from the sale of Albizia logs to village middlemen. In other words, the albizia has been culturally adopted by the Outer Baduy due to its suitability with the local ecological and social-cultural Baduy community. Unlike albizia, the coffee trees, however, are still prohibited to be cultivated in Baduy Area. However, the robusta coffee (Coffea canephora Pierre ex A. Froehner) trees have been cultivated predominantly in the traditional agroforestry of the forest hamlet (dukuh lembur) of Outer Baduy because the robusta coffee has provided some ecological and economic benefits, but not disturb the practice of the traditional swidden farming of the Outer Baduy.

Some studies on cultivation of coffee trees, including the ecological historical of coffee in Java, the introduction of coffee in forest by Perhutani program, various managements of coffee trees, the benefits coffee farming, and the role of animals in coffee pollination have been conducted by some scholars (Geertz 1963; Elson 1994; Widianingsih 2006; Zakaria 2009; Anggarani 2011; Subandi 2011; Lasmiyati 2015; Martini et al. 2017; Iskandar et al. 2018c). However, studies of coffee introduction and cultivation in the Outer Baduy area have rarely been conducted. Therefore, the objective of this study was to elucidate the ecological history of the coffee introduction, the traditional practice of the coffee tree cultivation, the plant composition of 'dukuh lembur' agroforestry, and the morale and interest of coffee introduction in the agroforestry of the outer Baduy.

\section{MATERIALS AND METHODS}

\section{Study sites}

This research was carried in the Outer Baduy area, namely the hamlets of Kaduketug, Kadujangkung, and Karahkal of Kanekese Village, Leuwidamar Sub-district, Lebak District, Banten Province, Indonesia (Figure 1).

Geographically the Baduy area of Kanekes village is located approximately between latitudes of $6^{0} 27^{\prime} 27^{\prime \prime}$ and $6^{0} 30^{\prime}$ North and between longitudes of $106^{0} 3^{\prime} 9$ " and $106^{0} 4^{\prime} 5^{\prime}$ "East. Based on the Baduy tradition, the Baduy community can be divided into two groups: Inner Baduy people (Urang Baduy Dalam or Urang Baduy Jero) and Outer Baduy people (Urang Baduy Luar or Urang Baduy Panamping) people. The Inner Baduy people live in three hamlets (kampung): Cibeo, Cikartawarna, and Cikeusik, while the Outer Baduy people reside in more than 55 hamlets, including Kaduketug, Kadujangkung, Gajeboh, Batara, and Gajeboh.

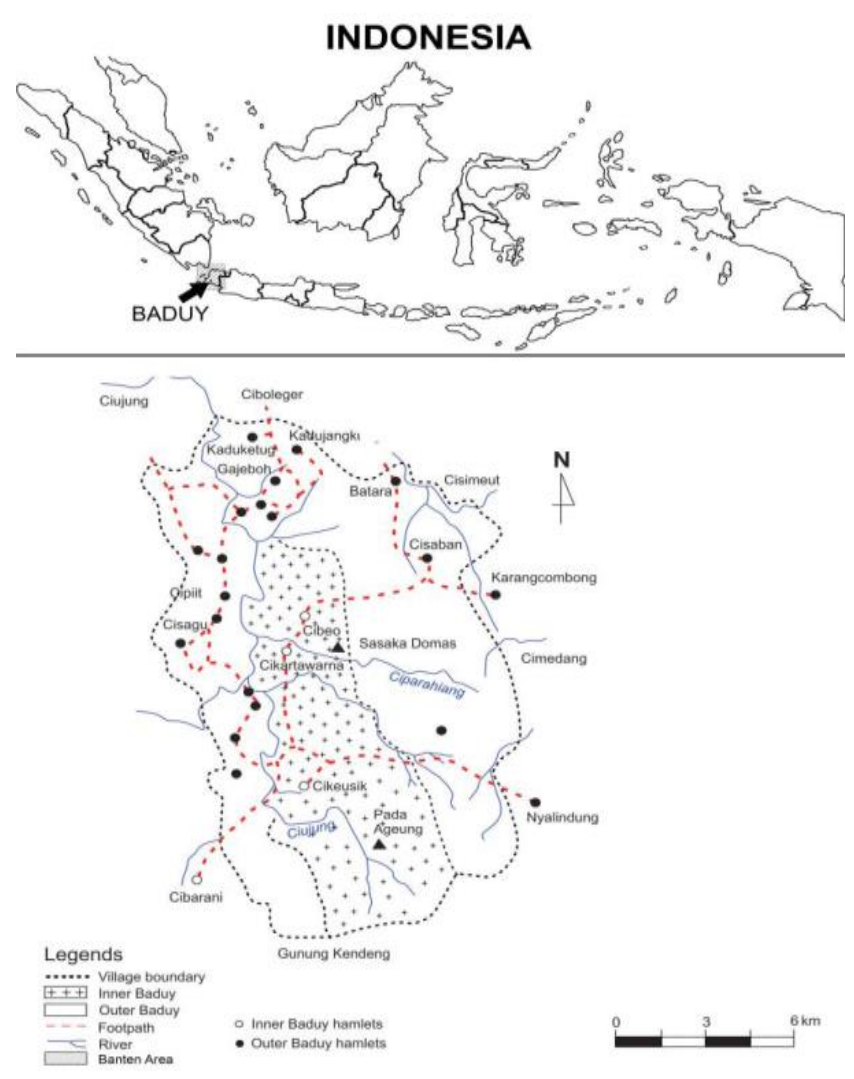

Figure 1. The Study site of the Baduy area of Kanekes Village, Leuwi Damar Sub-district, Lebak District, Banten, Indonesia (Iskandar et al. 2018a) 
In 2000 the estimated total population of Baduy community was 11,172 people, consisting of 5,624 males and 5,548 people, representing 2,948 households. Eight years later, in 2018 the total population of Baduy increased to 11,710 people, consisting of 5,884 males and 5,826 females, representing 3,414 households (Table 1). The population was dominated by the Outer Baduy people who constituted 89.6 percent of the total, and only 10.4 percent were the Inner Baduy people (Statistics of Kanekes village 2018).

The main subsistence of the Baduy community is an intensive practice of swidden cultivation (ngahuma). They manage the swidden farming based on traditional ecological knowledge (TEK) and beliefs. Each stage timing of the annual swidden farming activities is traditionally based on a special calendar named a pananggalan or kalender Baduy. Therefore, the pananggalan determines the timing of the Baduy community activities, such as swidden cultivation activities and annual ritual of Baduy community. One of the indicators for deciding new year of the Baduy calendar (pananggalan) is the belt of Orion (bentang kidang). The Baduy community is able to correlate to the positions of bentang kidang constellation to various activities in the swidden cultivation system. Therefore, the Baduy calendar plays a vital role as institutional instrument, designed to generate collective actions from the community members to get involved in various annual rituals (cf Khattri 2003; Franco 2015). In addition, the belief systems and rituals can often provide a strong sense of group solidarity that unifies different individuals of different backgrounds into a large and more cohesive unit and adaption functions for the human societies to their environment, and for the conservation of ecosystem (cf Lovelace 1984; Khattri 2003).

Table 1. Population of Baduy, Banten, Indonesia in 2000-2018

\begin{tabular}{cccc}
\hline Year (year) & $\begin{array}{c}\text { Time } \\
\text { (year) }\end{array}$ & $\begin{array}{c}\text { Population } \\
\text { (people) }\end{array}$ & $\begin{array}{c}\text { Change in number } \\
\text { (people) }\end{array}$ \\
\hline $2000-2008$ & 8 & $7,317-10,941$ & 3,624 \\
$2008-2010$ & 2 & $10,941-11,172$ & 231 \\
$2010-2015$ & 5 & $11,172-11,620$ & 448 \\
$2015-2017$ & 2 & $11,620-11,699$ & 79 \\
$2017-2018$ & 1 & $11,699-11,710$ & 11 \\
\hline
\end{tabular}

Source: Iskandar et al. (2018b); Village Statistics (2018)

Table 2. Various non-rice crop products commonly traded by Baduy, Banten, Indonesia in 2003/2004-2017/2018

\begin{tabular}{|c|c|c|c|}
\hline Non-rice products & $\begin{array}{l}\text { Market value (rupiah) in } \\
2003 / 2004\end{array}$ & $\begin{array}{l}\text { Market value (rupiah) in } \\
2017 / 2018\end{array}$ & Notes \\
\hline $\begin{array}{l}\text { Albasiah (Paraserianthes } \\
\text { falcataria (L) Nielsen) }\end{array}$ & $\begin{array}{l}10,000 \text { per tree; } 500,000- \\
1,000,000 \text { per plot }\end{array}$ & $60,000-65,000$ per tree & $\begin{array}{l}\text { After } 4-5 \text { years old, trees are cut and } \\
\text { sold to village middlemen. }\end{array}$ \\
\hline $\begin{array}{l}\text { Kopi (Coffea robusta Pierre } \\
\text { ex A. Froehner)* }\end{array}$ & $5,000 / \mathrm{kg}$ dried seeds & $25,000 / \mathrm{kg}$ & $\begin{array}{l}\text { Seeds are dried and sold to village } \\
\text { middlemen or district market. }\end{array}$ \\
\hline $\begin{array}{l}\text { Coklat, kakao (Theobroma } \\
\text { cacao } \mathrm{L})\end{array}$ & $3,000 / \mathrm{kg}$ dried seeds & $20,000 / \mathrm{kg}$ & $\begin{array}{l}\text { Seeds are dried and sold to village } \\
\text { middlemen or district market. }\end{array}$ \\
\hline $\begin{array}{l}\text { Kadu, durian (Durio } \\
\text { zibethinus Murr) }\end{array}$ & $\begin{array}{l}5,000 \text { per fruit, } 1,500- \\
2,000 / \text { per tree }\end{array}$ & $13,000-50,000$ per fruit & $\begin{array}{l}\text { Fruit is commonly sold to village } \\
\text { middlemen before rice harvest. }\end{array}$ \\
\hline $\begin{array}{l}\text { Cau, banana }(\text { Musa } x \\
\text { paradisiaca } \mathrm{L}) \text {, galek or } \\
\text { tanduk varieties }\end{array}$ & $\begin{array}{l}400-500 \text { per fruit, } 4,000- \\
5,000 \text { per bunch, } 20,000- \\
25,000 \text { per tree }\end{array}$ & 2,500 per fruit & $\begin{array}{l}\text { Bananas are harvested and bought by } \\
\text { village middlemen; carried and sold } \\
\text { to non-Baduy middlemen. }\end{array}$ \\
\hline $\begin{array}{l}\text { Cau, banana }(\text { Musa } x \\
\text { paradisiaca } \mathrm{L}), \text { other } \\
\text { varieties }\end{array}$ & 500 per bunch, 5,000 per tree & 2,000 per fruit & $\begin{array}{l}\text { Bananas are harvested and bought by } \\
\text { village middlemen, carried and sold } \\
\text { to non-Baduy middlemen. }\end{array}$ \\
\hline $\begin{array}{l}\text { Peuteuy, petai (Parkia } \\
\text { speciosa Hassk) }\end{array}$ & $\begin{array}{l}500 \text { per pod, } 50,000 \text { per } \\
\text { papan or ten pods; } 100,000- \\
200,000 \text { per tree }\end{array}$ & $\begin{array}{l}2,500 \text { per pod, } 25,000 \text { per } \\
\text { papan or ten pods }\end{array}$ & $\begin{array}{l}\text { Pods are commonly sold to village } \\
\text { middlemen before rice harvest, } \\
\text { carried and sold to non-baduy } \\
\text { middlemen. }\end{array}$ \\
\hline $\begin{array}{l}\text { Gula kawung, aren sugar } \\
\text { (Arenga pinnata Merr) }\end{array}$ & $\begin{array}{l}2,000-2,500 \text { per portion; } \\
200,000-2500,000 \text { per month }\end{array}$ & $6,500-7,500$ per portion & $\begin{array}{l}\text { Each piece of sugar is wrapped in dry } \\
\text { banana or salak leaves and sold to } \\
\text { village middlemen. }\end{array}$ \\
\hline $\begin{array}{l}\text { Rinu, pepper (Piper cubeba } \\
\text { L) }\end{array}$ & $\begin{array}{l}20,000-25,000 \text { per kg dry } \\
\text { seeds; } 200,000-250,000 \text { per } \\
\text { tree }\end{array}$ & 120,000 per kg dry seeds & $\begin{array}{l}\text { Seeds are dried and sold to village } \\
\text { middlemen or district market. }\end{array}$ \\
\hline $\begin{array}{l}\text { Kalapa, coconut }(\text { Cocos } \\
\text { nucifera }(\mathrm{L})\end{array}$ & 200 per unit; 10,000 per tree & 1,400 per unit & $\begin{array}{l}\text { Fruit is harvested and sold to village } \\
\text { middlemen }\end{array}$ \\
\hline $\begin{array}{l}\text { Cengkeh (Syzygium } \\
\text { aromaticum (L.) Merr \& L. } \\
\text { Ferry)* }\end{array}$ & $\begin{array}{l}27,000 \text { per kg dry flower } \\
\text { bud, } 270,000 \text { per tree }\end{array}$ & $100,000 / \mathrm{kg}$ & $\begin{array}{l}\text { Buds are dried and sold to village } \\
\text { middlemen. }\end{array}$ \\
\hline
\end{tabular}




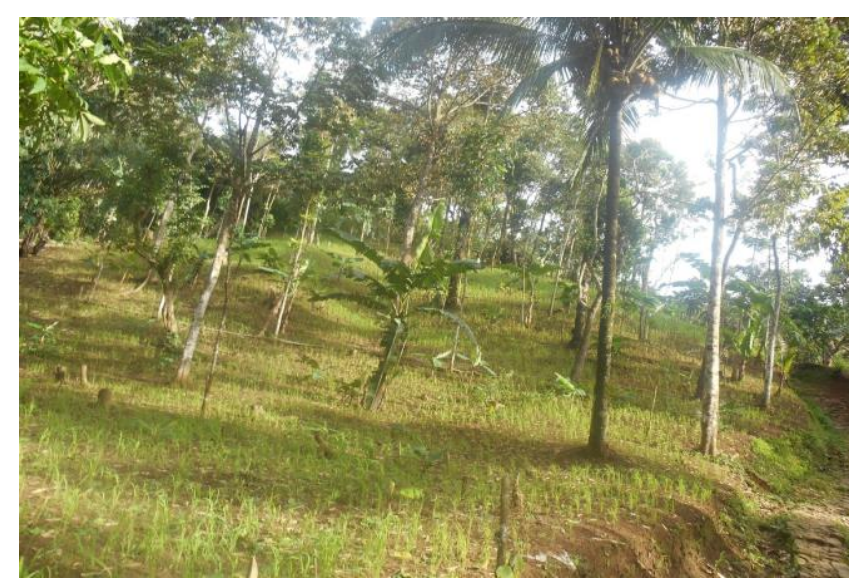

Figure 2. The Outer Swidden cultivation system that is being planted with rice and other crops, including banana, coconut, durian and jengkol

Since the rice is perceived to have a Goddess called Nyi Pohaci, the swidden rice is highly respected. Indeed, the swidden rice (pare huma) is prohibited to trade, and is traditionally put in the rice barns (leuit) for some decades and can be inherited by their children. The swidden rice is mainly used for various traditional rituals and for daily home consumption, particularly if they do not have enough money to buy the sawah rice (beas sawah) from village small shops in neighboring Baduy area. Unlike rice, various non-rice crop productions, including kadu/durian (Durio zibethinus Murr), cau/banana (Musa x paradisiaca L), and peuteuy/petai (Parkia speciosa Hassk) (Table 2) are allowed to sell to get cash income to buy various daily household needs, including sawah rice, salted fish, salt, and cooking oil.

According to the Baduy tradition, each household must conduct the swidden farming (ngahuma) which is considered as an obligation for their religion called Sunda Wiwitan or Agama Baduy. Conversely, the cultivation of the irrigated wet rice farming (sawah) is prohibited. In addition to upland rice crop (Oryza sativa L), various other annual and perennial crops, including hiris (Cajanus cajan (L) Missp), bonteng (Cucumis sativus L), jagung (Zea mays L), cau/pisang (Musa x paradisiaca L), durian (Durio zibethinus L), petai, aren/kawung (Arenga pinnata Merr), and jengkol (Achidendron pauciflorum (Benth) I.C. Nielsen) are predominantly planted in the swidden farming system (Figure 2).

Because the swidden farming system is planted with various annual and perennial crops, the swidden system is categorized as traditional agroforestry. The Agroforestry may be defined as a collective name for land-use system and technologies where woody perennials are deliberately used on the land-management units as agricultural crops and/or animals, in some forms of spatial arrangement or temporal sequence (Raintree and Warner 2015).

Other traditional agroforestry types of Baduy are found namely the fallowed secondary forest system (reuma system) and hamlet forest (dukuh lembur or leuweung lembur). The reuma can be divided into two categories, the immature fallowed secondary forest (reuma ngora) that is

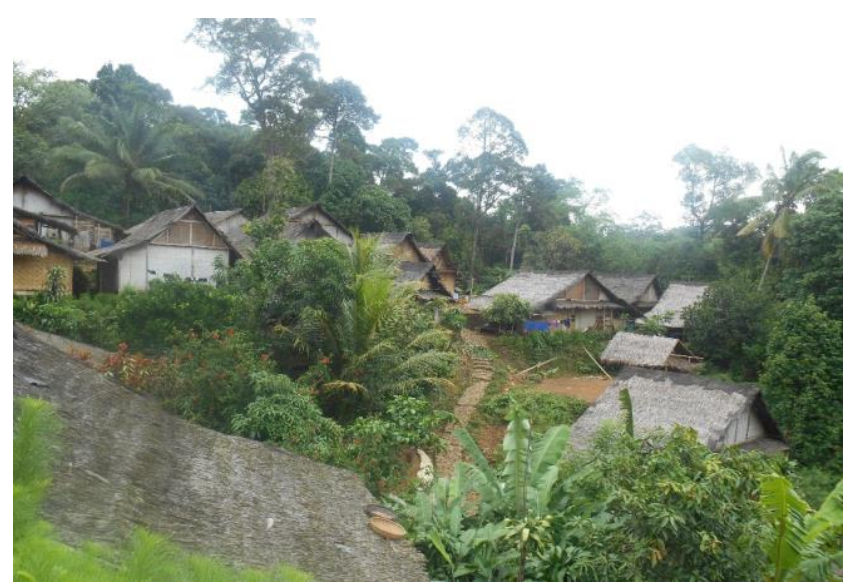

Figure 3. Dukuh lembur of Outer Baduy surrounding a hamlet (kampung) predominantly planted fruit trees and other perennial plants

swidden fallowed land fallowed less than three years, and the mature fallowed secondary forest (reuma kolot). The hamlet forest is the land located around hamlet that is predominantly planted with perennial crops, including durian, petai, bamboo (Gigantochloa spp), jengkol (Achidendron pauciflorum (Benth) I.C. Nielsen), and kalapa/coconut (Cocos nucifera L). Because the dukuh lembur is prohibited to be converted into swidden, the structure vegetation is similar to that of the natural forest. Various non-rice crop productions, including fruits (durian, rambutan, mango), vegetables (petai, jengkol), industrial plants (aren, coffee), and building materials (albizia, bamboo) can be harvested for both home consumption and commercials (Figure 3).

\section{Research procedures}

This research was a qualitative one. Data collection was conducted through observation, semi-structured interviews, participant observation, and recording of plant species (Newing et al. 2011; Albuquerque et al. 2014; Iskandar 2018). Observation was undertaken to record the ecological conditions of the Outer Baduy settlement, and various types of traditional agroforestry systems, including the swidden field (huma), swidden fallowed land (reuma), and hamlet forest (dukuh lembur or leuweung lembur).

Semi-structure interviews were conducted with purposively selected informants, consisting of the village leader (Jaro Paramentah) and his staff (Carik Desa), old male farmers, old female farmers, and village middlemen (bandar desa). Participant observation was done, in which the researchers accompanied informants both to observe what they did and also to participate in some activities, including planting, weeding, harvesting, and processing of coffee fruit, and asked some questions of their activities.

Inventory of plant species of surrounding coffee trees in the mixed-garden of dukuh lembur was carried out by recording each plant species at 5 sampling plots, each measuring $10 \mathrm{~m}$ x $10 \mathrm{~m}$. Each tree species was recorded including the number of individuals, whereas for each shrub undergrowth species (shrub, herb, and seedling) only the species name was recorded. Several field guide books 
for the plant identifications, including Balgooy (1997, 1998, 2001) and Heyne (1987) were used to identify various plant species found in the sample plots of the $d u k u h$ lembur.

\section{Data analysis}

The data were analyzed by cross-checking, summarizing, synthesizing, and making narrative (Newing et al. 2011). The cross-checking and triangulation were done to get valid data based on information from observation, participant observation, and informants. Moreover, it was summarized, synthesized and made narrative with descriptive and evaluative analyses.

The perennial plant species recorded in the plots were analyzed using index of Summed Dominant Ratio (SDR) (Iskandar and Iskandar 2016). SDR was calculated using the following formula:

$$
S D R=\frac{F r+D r}{2} x 100 \%
$$

Where,

$$
\mathrm{Fr}=\frac{\text { Frequency of certain plant species }(\mathrm{F})}{\text { Total frequency of total plant species }} \times 100 \%
$$

$$
\mathrm{Dr}=\frac{\text { Individual of certain plant species (D) }}{\text { Total individual of all plant species }} \times 100 \%
$$

Where:

$\mathrm{F}=$ absolute frequency of certain plant species, which is the number of sample plots containing a particular species

$\mathrm{Fr}=$ Relative frequency, which is the frequency of certain species divided by total frequency of total species in percent

$\mathrm{D}=$ number of individuals belonging to certain plant species

Dr $=$ the proportion of plant individuals of certain species of all plant individuals of the community in percent

A species had a high SDR if it was recorded in many plots (high frequency) with high individual number (dominant).

\section{RESULTS AND DISCUSSION}

\section{Ecological history of coffee Introduction in the Outer Baduy}

According to ecological history, coffee trees were introduced in South Banten a long time ago. Iskandar (1998) said that coffee trees, and other crops, including indigo, sugarcane, tobacco, and cinnamon were first introduced in Banten at the beginning of the cultivation system (culture stelsel) in Java during 1830. Unlike other crops, coffee trees were relatively successfully introduced in the forest and dry land area and production peaked in 1863-1865. These were planted in swiddens as well, particularly on hillsides, because small gardens could be sacrificed with less pressure on subsistence cultivation.
In the neighboring Baduy area, coffee trees have been recorded since the 1830s (cf. Geertz 1963; Elson 1994). According to the Outer Baduy informants, coffee trees were introduced and planted in the Outer Baduy area in 1980s. The seedlings of coffee (Coffea canephora Pierre ex A. Froehner) trees have been planted in the mixed-garden of dukuh lembur, not in the swidden plots (huma). They got the coffee seedlings from the neighboring non-Baduy areas by collecting the seedlings.

Because according to the Baduy tradition coffee trees are prohibited to plant in Baduy areas, some coffee seedlings were uprooted by informal leader's (Puun) staff (Jaro Tangtu) from the Inner Baduy during the rituals for purification of tradition (pembersihan adat). As a result, all trees disappeared. It has been known that according to the Baduy tradition, every two years in month of Kalima of Baduy calendar, special rituals for purification of tradition (pikukuh) is usually undertaken. On these occasions, prohibited luxury and 'modern' goods and prohibited cash crops, such as coffee trees, are destroyed by the Puun staff of Inner Baduy (Iskandar 1998).

Historically, although a lot of coffee trees in Outer Baduy have been destroyed many times, the Outer Baduy people have never stopped planting because of the benefits for home consumption and cash income from coffee trees. Traditionally the coffee trees have been planted in the hamlet forest (dukuh lembur or leuweung lembur), but they never have been planted in mixed plantation with rice crop in the swidden plot due to prohibition by the Baduy tradition.

Today the coffee trees have predominantly been found in the dukuh lembur of the Outer Baduy. During the annual purification of tradition at the month of Kalima, at the starting of rice planting of the sacred swidden plot (ngaseuk huma serang) of Inner Baduy, the coffee trees planted in Outer Baduy have been cut by the Puun's staff (Jaro Tangtu). However, the coffee trees have been existing in the Outer Baduy areas because they were just cut instead of being uprooted, so some shoots can properly grow and later on can produce fruit. In addition, during the destruction, only some of the coffee trees were cut, particularly those planted along the footpaths, but some coffee trees planted far from the footpaths were not cut.

\section{Traditional practice of coffee cultivation in Outer Baduy}

The Outer Baduy people have not yet intensively farmed the coffee trees. Because according to the Baduy tradition, initially the coffee trees are prohibited (tabu or teuwasa) to cultivate in Baduy area, the coffee trees have been integrated into traditional agroforestry of the dukuh lembur. Traditionally, there are five stages of the coffee cultivation in Outer Baduy, namely seed preparation, planting, maintenance, harvesting, and utilization of coffee productions.

\section{Seed preparations}

The Outer Baduy people have selected the coffee of robusta (Coffea canephora Pierre ex A. Froehner) for their farming, integrated in the traditional agroforestry of the 
village forest (dukuh lembur). Scientifically, coffee trees are best planted in areas with annual precipitation of 1,500 to $3,500 \mathrm{~mm}$, with maximum of 3 dry months (precipitation less than $60 \mathrm{~mm}$ ) (Martini et al. 2017). Robusta coffee that has large and thin leaves is best planted in elevations ranging from 40 to $900 \mathrm{~m}$ above sea level (masl). Therefore, this coffee species are considered to be appropriately cultivated in Baduy area that is located in between $200-450 \mathrm{~m}$ asl.

Unlike non-Baduy people, the Outer Baduy people obtain the coffee seedlings (petétan kopi) by collecting them from their mixed-garden and/or from the mixedgarden belonging to other people by asking permission first. The coffee seedlings are predominantly found in the mixed garden because mature seeds were spread out by small bats (lalay) from the parent trees. Generally, bats are important as seed dispersal in tropical forest ecosystem (Aguilar-Garavito et al. 2014). Ecologically, insect-eating bats are important in pest control, whereas fruit-eating bats are important in plant pollination and seed dispersal. For example, in India, fruit-eating bats are the sole or key pollinators of many plants, including many economically important species, such as durian (Durio sp.) and wild banana (Musa sp.) (Wordley et al. 2014), while in Indonesia some fruit-eating bats play a vital role in seed dispersal of various economically valuable fruits, including duwet (Syzygium cumini (L) Skeel), sawo (Manilkara zapota (L) van Royen), and srikaya (Annona squamosa L) (Suyanto 2001; Soegiharto et al. 2010; Prasetyo et al. 2011).

The coffee seeds are usually found scattered on the ground of dukuh lembur spread by small bats, and grow into seedlings. The small bats picked mature coffee fruit at night, eating it, but some of the beans fall on the ground and finally germinate into seedlings, and are commonly collected by Outer Baduy people.

\section{Coffee seedling planting}

The coffee seedlings are commonly planted in the traditional agroforestry system of the hamlet forest (dukuh lembur) of Outer Baduy area. Before planting the coffee seedlings, the land preparation is undertaken with very simple technique. The main work is making planting 2 meter-deep holes using small hoes (kored), 2 meters apart from each other. Each individual 0.3-0.5 meter-high seedling is put in the planting hole and covered with soil. So, the coffee seedlings are planted in a mixed plantation with other plants in the dukuh lembur. In some cases, the coffee seedlings are planted near the trees of dadap berduri (Erythrina variegata L) and dadap tak beduri (Erythrina subumbrans (Hassk) Merr). Integration of coffee trees with the two species of trees has resulted in some benefits, including increased soil fertility because these species are nitrogen-fixing legumes that can be used as green manure (Reijentjes et al. 1992). In addition, the dadap trees can be used as a support for a species of pepper called rinu, which is a climber (Piper cubeba L).

Both crop species, coffee, and rinu have important economic value because their products are commonly traded to obtain cash income of the Outer Baduy people (Iskandar 2007). Thus, a mixed plantation of nitrogen- fixing trees and commercial crops is commonly adopted by traditional farmers as a method for sustainable traditional swidden farming system which can maintain soil fertility and enhance the household income (Erni 2006; Bunch 2015; Garrity 2015; Ramakrishnan 2015; Raintree and Warner 2015).

\section{Coffee tree maintenance}

The maintenance of the coffee trees in the traditional agroforestry systems of the Outer Baduy is not intensively conducted, mostly just clearing the weeds growing around the coffee trees, using a special sickle called kujang (Figure 4).

The clearing of weeds (disasapan) is aimed to avoid competition of nutrients between coffee trees and the weeds. In addition, the young shoots that grow densely on the stem are pruned (ditunas or disirung) so that the coffee trees get sufficient sunlight. The Traditional Ecological Knowledge (TEKS) of the Outer Baduy concerning pruning of young shoots (emic view) is similar to the Western scientific knowledge (ethic view) in stimulating the process of flowering and pollination, providing branches for the next harvest, and facilitating harvest (Martini et al. 2017).

The pest control of the coffee trees of the traditional agroforestry of the dukuh lembur systems of the Outer Baduy is different from that of the modern coffee farming system of non-Baduy. According to the informants, the Outer Baduy coffee tree farming systems are rarely attacked by diseases and pests. As a result, pest control is rarely done in Outer Baduy coffee farming. Conversely, pest control of the modern coffee farming in non-Baduy is often conducted because the coffee trees are commonly attacked by various diseases and pests, including borers which usually attack the stems and branches, nematodes which attack the roots, and fungi attack leaves, stems and roots of coffee trees (Anggarani 2011; Subandi 2011; Hulupi and Martini 2013; Martini et al. 2017). The Outer Baduy coffee farming system is rarely attacked by pests because the diverse agroforestry system has strong resistance to pest attack and to complete crop losses caused by environmental stresses, including climate changes (Aryal and Choudury 2015). In addition, the coffee trees under shade experience less stress of climate than those with no shade.

Thus, shade trees in agroforestry system maintain the microclimate of the mixed-garden. The shade trees protect the coffee trees from the increased air temperatures. Moreover, the litter of shade trees provides additional nutrient for soil and maintains soil humidity, particularly during the prolonged drought and when the temperature increases (Martini et al. 2017). Since the traditional agroforestry system with coffee trees has a lot of litter consisting of dry leaves and dry twigs which provide nutrients for plants, inorganic fertilizers are not provided. So, in general, the Outer Baduy community has practiced organic farming that encourages healthy soils and crops through the avoidance of synthetic fertilizers and pesticides (Reijentjes et al. 1992). 


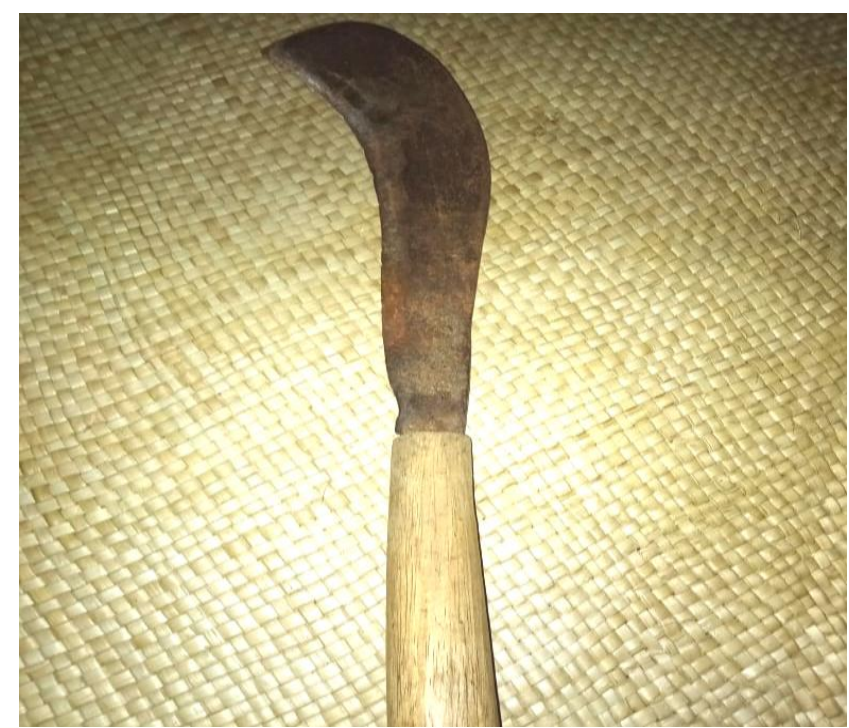

Figure 4. The Outer Baduy sickle (kujang) is traditionally used to cut terrestrial weeds growing near the coffee trees.

\section{Harvesting of coffee trees}

The coffee trees planted from the 0.3-0.5 meterseedlings may produce fruit 3-4 years after planting, while those sprouting from the old stumps of older trees that have been cut by informal leader staff (Jaro Tangtu) during the rituals for purification of tradition, usually produce fruits 11.5 years after sprouting. However, its fruit can be harvested approximately 1-2 months after fruiting.

Harvesting of fruit is annually done by picking of ripe fruit (memilih buah kopi kolot) marked by red color (Figure 5). Each household of Outer Baduy has approximately 50 coffee trees. The coffee production in Outer Baduy is approximately $2 \mathrm{~kg} /$ tree, and if a farmer plants about 50 trees in one block of the dukuh lembur, he or she may get 2 $\mathrm{kg} \times 50$ individuals $=100$ kilograms of the fresh coffee fruit. The production of robusta coffee of Outer Baduy is lower than that of arabica coffee in the agroforestry system of the Perhutani (a state-owned forest company) forest of Palintang which is $3 \mathrm{~kg} /$ tree, because the cultivation coffee trees in the Outer Baduy area is is less intensive than that of Perhutani. For example, some inputs of production, including the organic fertilizers of compost or animal dung to increase soil fertility are usually provided in the coffee agroforestry system of Palintang (Iskandar et al. 2018c).

\section{Processing and utilization of the coffee production}

There are several stages of the traditional processing of fresh coffee fruit to become dry beans and ready to be sold or to be made a beverage for home consumption. First, the harvested coffee fruit from the dukuh lembur is brought to hamlet. Second, the fresh fruit is pounded (ditutu) in a wooden mortar (jubleg), and winnowed using a big round tray (nyiru) to remove the skin (Figure 6a). Third, the pounded coffee beans are dried under blazing sunlight on nyiru or Pandanus mat (samak pandan) in front of the homegarden for a week depending on daily weather condition (Figure 6b). Forth, the dry coffee beans are ready

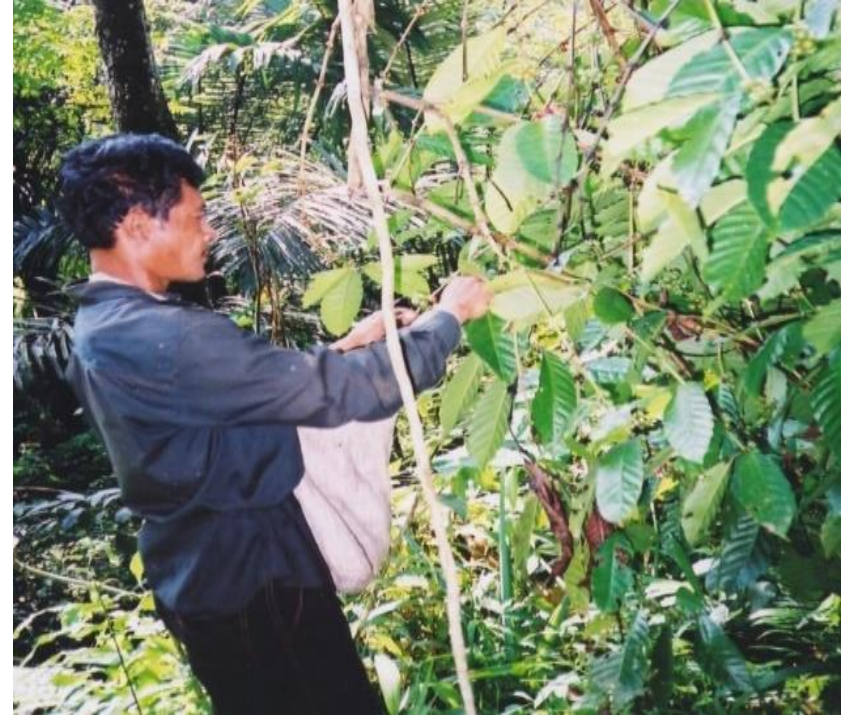

Figure 5. The Robusta coffee fruit is being harvested by a man of Outer Baduy

to be sold or to be continuously processed for home consumption.

In general, the utilization of the coffee production of Outer Baduy may be divided into two categories: economic subsistence and commercial purposes. The coffee production is used for the economic subsistence purposes if an Outer Baduy family has a small number of coffee trees in his mixed-garden. Traditionally, for household consumption, dry coffee beans are processed by women. First, the dry beans are dry-fried (disangray) in a big kettle (kékéncéng) on the stove. Then, the fried beans are pounded in a wooden mortar. Finally, the coffee powder is filtered with a filter, and the fine is put in a jar, while the coarse one is re-pounded to make it finer. The coffee is ready to be brewed with hot water in a kettle (téko) and served in a cup. According to the tradition, most Outer Baduy people have a habit of drinking coffee at least twice a day, in the morning (nginum kopi isuk-isuk) and the afternoon (minum kopi sore), and eat some traditional foods, including boiled cassava, boiled sweet potato, and brown sugar (gula kawung) at the same occasion.

For the commercial purposes, particularly for the Outer Baduy households who have at least 50 coffee trees in the mixed-garden, part of the coffee production surplus is commonly sold to the village middlemen. The robusta coffee beans are locally named kopi bebek (pounded coffee), but they are called kopi padasuka by non-Baduy people. Traditionally, the dry coffee beans of the Outer Baduy are mostly sold to the village middlemen who usually buy various non-rice products, including coffee beans (Coffea canephora Pierre ex A. Froehner), bananas (Musa paradisiaca L), durian (Durio zibethinus Murr), petai (Parkia speciosa Hassk), and coconuts (Cocos nucifera L). Subsequently, this agricultural produce is brought by the middlemen to district capital, Rangkasbitung, to sell to the city middlemen. 


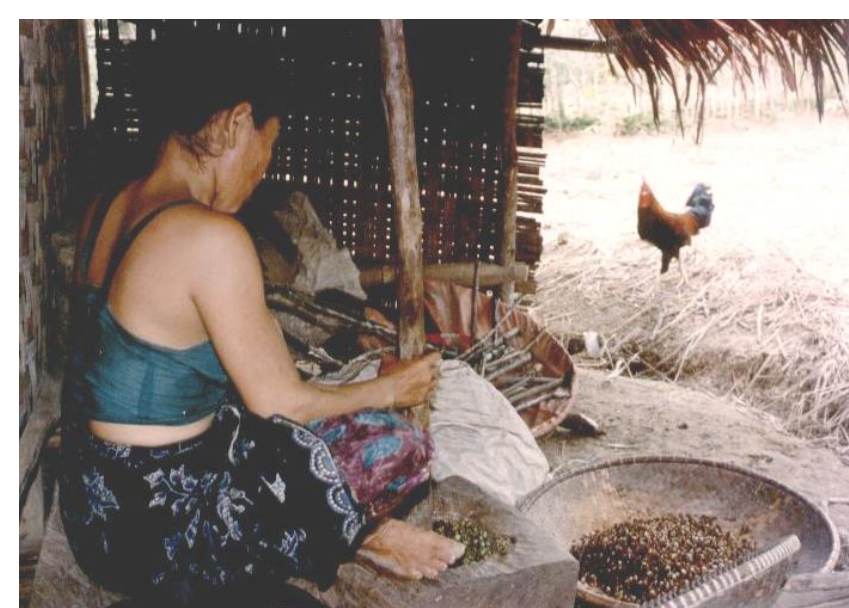

Figure 6.A. The coffee fruit in the wooden mortar (jubleg) is being pounded by an Outer Baduy woman.

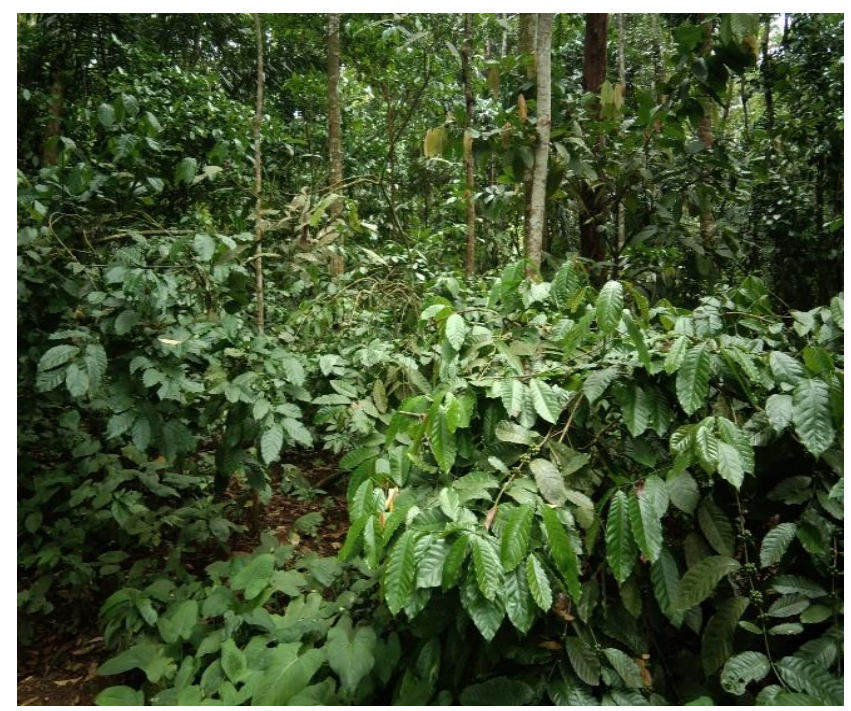

Figure 7.A. The coffee trees are predominantly planted in a mixed plantation with other perennial crops of the Outer Baduy agroforestry of dukuh lembur

In 2018, the dry coffee beans were predominantly sold in the Outer Baduy of Kanekes Village at a price of Rp $25,000 / \mathrm{kg}$. Therefore, if one household had 50 coffee trees in the mixed-garden with production of $2 \mathrm{~kg} / \mathrm{tree}$, the total production of fresh coffee fruit was $100 \mathrm{~kg}$, and after having been dried and pounded, the dry beans became 50 $\mathrm{kg}$. If all the dry coffee production was sold, the Outer Baduy farmer might get Rp 1,250,000, -/year cash money. Meanwhile, the price of hulled rice of sawah in small shops (warung) in 2017/2018 was $\mathrm{Rp} 8,500-10,000 /$ liter. Therefore, production of 50 coffee trees cultivated in the

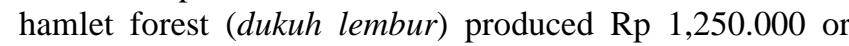
equivalent to $125-147$ liters/year or $14,8-17,5 \%$ of total swidden rice production because the rice production of 0.6 ha swidden plot was approximately 840 liters/year (Iskandar 2007). Accordingly, the cultivation of coffee trees in the forest hamlet (dukuh lembur) has provided benefits for both the subsistence and commercial purposes of the Outer Baduy people.

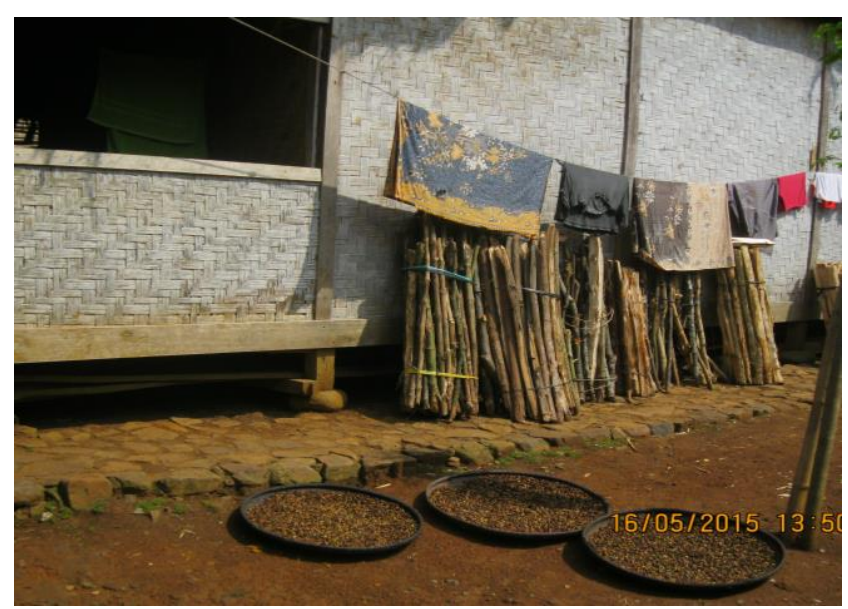

Figure 6.B. The coffee beans on a big flat bamboo tray (nyiru) in the homegarden are being dried with blazing sunlight.

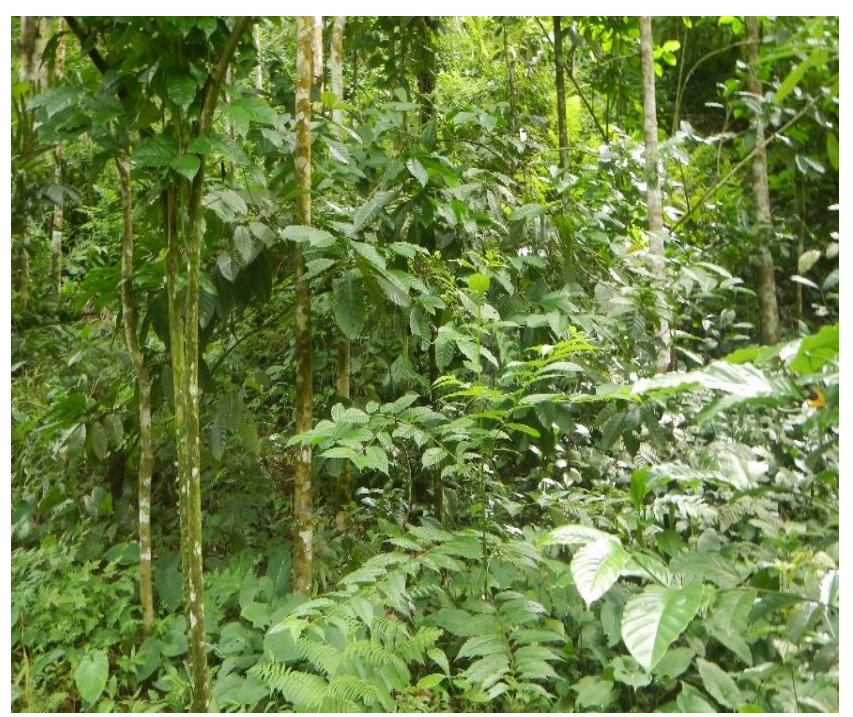

Figure 7.B. Various undergrowth plants, i.e., herbs and shrubs are found in the Outer Baduy Agroforestry system with coffee trees

\section{Plant composition of the dukuh lembur-agroforestry coffee}

According to the Baduy tradition, traditionally the coffee and clove trees are prohibited to plant in the monoculture system in Baduy area because these crops are considered as new crop of the colonial crop (tanaman baru or tanaman colonial). Although the coffee trees are prohibited to plant in Baduy area, the robusta coffee trees have been farmed and properly integrated into the traditional agroforestry of the hamlet forest system (dukuh lembur) by the Outer Baduy people. These coffee trees are planted in a mixed plantation of various perennial plants in the form of the traditional agroforestry system that provides a wide range of products with a high nutritional value, namely fruits and vegetables and other products, such as building materials, firewoods, traditional medicines, and handicraft materials (Figure 7.A). In addition, under coffee trees, various undergrowth plants, i.e., herbs and shrubs are found (Figure 7.B). 
Table 3. Coffee trees and other tree crops in the mixed-garden (dukuh lembur) of the Outer Baduy, Banten, Indonesia

\begin{tabular}{|c|c|c|c|c|}
\hline Local name & Scientific name & Family & Main function & $\begin{array}{c}\text { Summed } \\
\text { Dominant } \\
\text { Ratio/SDR }(\%)\end{array}$ \\
\hline Kopi & $\begin{array}{l}\text { Coffea canephora Pierre ex A. } \\
\text { Froehner }\end{array}$ & Rubiaceae & $\begin{array}{l}\text { Coffee powder is used to make beverage and } \\
\text { sold to village middlemen }\end{array}$ & 21.29 \\
\hline Kawung, aren & Arenga pinnata (Wurmb) Merr. & Arecaceae & $\begin{array}{l}\text { Inflorescence is used to make brown sugar } \\
\text { (gula kawung) }\end{array}$ & 9.49 \\
\hline Coklat & Theobroma cacao $\mathrm{L}$ & Malvaceae & Dried seeds are sold to village middlemen & 8.42 \\
\hline Kadu, durian & Durio zibethinus L. & Malvaceae & Fruit is commonly sold to village middlemen & 8.42 \\
\hline Kokosan & Lansium domesticum cv. kokosan & Meliaceae & Fruit is commonly sold to village middlemen & 5.97 \\
\hline Mahoni & Swietenia macrophylla King & Meliaceae & $\begin{array}{l}\text { Stems are used as building material, } \\
\text { firewood, bark as coloring agent, and seeds } \\
\text { as traditional medicines }\end{array}$ & 5.27 \\
\hline Peuteuy & Parkia speciosa Hassk. & Leguminosae & $\begin{array}{l}\text { Pods are commonly sold to village } \\
\text { middlemen }\end{array}$ & 5.27 \\
\hline Lame & Alstonia scholaris (L) R.Br & Apocynaceae & $\begin{array}{l}\text { Stems are used as firewood, barks as } \\
\text { traditional medicines }\end{array}$ & 3.52 \\
\hline Tundun, rambutan & Nephelium lappaceum $\mathrm{L}$. & Sapindaceae & Fruit is commonly sold to village middlemen & 3.52 \\
\hline Kalapa, kelapa & Cocos nucifera $\mathrm{L}$. & Arecaceae & Fruit is sold to village middlemen & 3.52 \\
\hline Kacapi, kecapi & $\begin{array}{l}\text { Sandoricum koetjape (Burm.f.) } \\
\text { Merr. }\end{array}$ & Meliaceae & Fruit is sold to village middlemen & 3.52 \\
\hline Ki awi & Agathis alba (Lam.) Foxw. & Araucariaceae & Wood is used as material to make 'kolecer' & 2.45 \\
\hline Nangka & Artocarpus heterophyllus Lam. & Moraceae & Fruit is sold to village middlemen & 1.76 \\
\hline Dukuh & $\begin{array}{l}\text { Lansium parasiticum (Osbeck) } \\
\text { K.C. Sahni \& Bennet }\end{array}$ & Meliaceae & Fruit is sold to village middlemen & 1.76 \\
\hline Lengkeng & Dimocarpus longan Lour. & Sapindaceae & Fruit is used for the home consumption & 1.76 \\
\hline Sobsi & Maesopsis eminii Engl. & Rhamnaceae & Wood is used as firewood & 1.76 \\
\hline Salak & Salacca zalacca (Gaertn.) Voss & Arecaceae & Fruit is used for home consumption & 1.76 \\
\hline Kapundung & $\begin{array}{l}\text { Baccaurea racemosa (Reinw. ex } \\
\text { Blume) Müll.Arg. }\end{array}$ & Phyllantaceae & $\begin{array}{l}\text { Fruit is used for home consumption, and } \\
\text { wood as building material }\end{array}$ & 1.76 \\
\hline Tangkil & Gnetum gnemon L. & Gnetaceae & Fruit and leaves are used for vegetable soup & 1.76 \\
\hline Solempa & Homalomena sp & Araceae & & 1.76 \\
\hline Kihiang & Albizia procera (Roxb.) Benth & Fabaceae & $\begin{array}{l}\text { Wood is used as building material and } \\
\text { firewood }\end{array}$ & 1.76 \\
\hline Jatake & Bouea macrophylla Griff. & Anacardiaceae & $\begin{array}{l}\text { Fruit is used for home consumption and } \\
\text { woods as building materials }\end{array}$ & 1.76 \\
\hline Jengkol & $\begin{array}{l}\text { Archidendron pauciflorum } \\
\text { (Benth.) I.C. Nielsen }\end{array}$ & Fabaceae & $\begin{array}{l}\text { Fruit is used for home consumption and sold } \\
\text { to middlemen }\end{array}$ & 1.76 \\
\hline
\end{tabular}

The survey of the mixed-garden plots recorded at least 41 plant species consisting of 23 trees and 18 undergrowth plants (shrub, herbs, and seedlings) (Tables 3 and 4). Some trees that had high SDR value in the mixed-garden, were kopi (Coffee canephora Pierre ex A.Froehner, SDR=21.29 $\%$, kawung/aren (Arenga pinnata (Wurmb) Merr, $\mathrm{SDR}=9.49$ ), coklat (Theobroma cacao L, SDR=8.42\%), kokosan (Lansium domesticum cv. Kokosan, SDR=5.27\%) and peuteuy (Parkia speciosa Hassk, SDR=5.27 \%. These trees are commercial crops traded in petty trading of the Outer Baduy, as non-rice crops produced from the swidden, fallowed secondary forest, and hamlet forest garden (Table 2). In addition, some undergrowth species also play vital roles for ecological and socio-cultural functions because these species can protect soil erosion and improve soil fertility, and provide food, traditional medicines, and materials for traditional rituals (Table 3).

\section{Moral versus interest}

The Outer Baduy people' live in a largely subsistence economy in which the swidden cultivation of rice (ngahuma) has been the main activity. In addition, they are engaged in various non-subsistence activities to earn cash for buying daily goods, including hulled sawah rice (beas sawah), salted fish, fish paste, salt, soya sauce, cooking oil, and kerosene. Cash earning activities, including trading handicraft products, getting involved in petty trading of non-rice crop products; working for wages both in Baduy and non-Baduy areas, and planting cash crop of albizia and coffee trees have been undertaken by Outer Baduy people. The strategy of Outer Baduy community that is engaged in subsistence and cash cropping has been widely found among swidden cultivators in Indonesia to maintain sustainability of the traditional swidden cultivation system (Sulistyawati 2011; Mashman and Nayoi 2015). 
Table 4. Various plants growing as undergrowth of coffee trees in the mixed-garden (dukuh lembur) in Outer Baduy

\begin{tabular}{|c|c|c|c|}
\hline Local name & Scientific name & Family name & Notes \\
\hline Areuy capituheur & $\begin{array}{l}\text { Mikania cordata (Burm.f) B.L. } \\
\text { Rob }\end{array}$ & Asteraceae & $\begin{array}{l}\text { A fast-growing plant which has a function to improve } \\
\text { soil fertility }\end{array}$ \\
\hline Cariang & Homalonema rubescens Kunth & Araceae & $\begin{array}{l}\text { Plant used for ritual of felling and pruning trees of rice } \\
\text { cultivation (narawas and nukuh) }\end{array}$ \\
\hline Cau, Pisang & Musa $x$ paradisiaca $\mathrm{L}$ & Musaceae & Fruit-producing plant \\
\hline Congkok & Curculigo capitulate & Hypoxidaceae & Herb \\
\hline Harendong bulu & Clidemia hirta D. Don & Melastomaceae & Shrub \\
\hline Ileus & Amorphophallus muelleri $\mathrm{Bl}$ & Araceae & Herb \\
\hline Kawung, Aren & Arenga pinnata (Wurmb) Merr. & Arecaceae & Seedling \\
\hline Ki seureuh & Piper aduncum $\mathrm{L}$ & Piperaceae & Good soil condition indicator \\
\hline Koneng gede & Curcuma xanthorrhiza Roxb & Zingiberaceae & Traditional medicine \\
\hline Kunci & Kaempferia rotunda $\mathrm{L}$ & Zingiberaceae & Spice \\
\hline Kunyit, Koneng & Curcuma longa $\mathrm{L}$ & Zingiberaceae & Spice, used for ritual of narawas and nukuh \\
\hline Pacing & Costus speciosus (J. Koenig) & Zingiberaceae & Plant used for storing rice in the rice barn \\
\hline Paku & Pteris sp & Pteridaceae & Herb \\
\hline Pulus & Acalypha boehmerioides Miq & Euphorbiaceae & Herb. \\
\hline Rane & Selaginella $\mathrm{sp}$ & Sellaginellaceae & Plant used for ritual of narawas and nukuh. \\
\hline Salak & Salacca zalacca (Gaertn.) Voss & Arecaceae & Seedling \\
\hline Sobsi & Maesopsis eminii Engl. & Rhamnaceae & Seedling \\
\hline Taleus & Colocasia esculenta $(\mathrm{L})$ Schott & Araceae & Additional staple food \\
\hline
\end{tabular}

Like other the traditional swidden cultivation systems in Indonesia, today the traditional Outer Baduy swidden farming has been facing various environmental and socialeconomic stresses, including decreasing forest area, climate changes, population increase, and intensive penetration of market economy (Iskandar 2007; Iskandar et al. 2018b). Therefore, the Outer Baduy community has developed cultural strategies to maintain sustainability of the swidden farming, that is considered as an obligation in their religion, and to fulfill the household income. For instance, although the coffee trees have been prohibited to plant in Outer Baduy area, some Outer Baduy people have cultivated these cash crops that are properly integrated into the traditional agroforestry of dukuh lembur. The production of the Outer Baduy coffee has been used predominantly for home consumption and some surpluses have also been traded to get cash income. Unlike rice, the cultivation of coffee trees has not been accompanied by various rituals because the coffee crop is not considered sacred.

Therefore, the Outer Baduy people have applied two models of economic behaviors, moral principle and cultural value (cf. Plattner 1989; Granoveter 1985). The swidden cultivation of planting rice is considered to be moral principle that is based on the Traditional Ecological System (TEK) and belief. According to the Baduy belief, the rice has Goddess, Nyi Phoci, so the rice must be respected and prohibited to sell. The production of the swidden rice has been used mainly for the traditional rituals including kawalu and ngalaksa, and for the home consumption, particularly if they do not have enough money to buy sawah rice, while non-rice crop products, including coffee product have been allowed to sell to get income.

This study provides a valuable lesson in exploring alternative development path for the Outer Baduy swidden agriculture system in response to the increasing population pressure, market economy penetration, and climate changes. The community living an area with a limited capacity for expansion, and an increasing various ecological and socio-economic stresses can develop cultural strategies. In this case, the Outer Baduy people have made various adaptations, such as cultivating cash crop of robusta coffee (Coffea canephora Pierre ex A. Froehner) in the traditional agroforestry of dukuh lembur. The cultivation of the robusta coffee, however, must be adapted to the ecological and socio-cultural aspects of the Baduy community. The cultivation of cash crop albizia and coffee are dissimilar in that the albizia has been fully integrated into the swidden cultivation because it provides benefits and strengthens the traditional swidden farming, while the coffee trees have been traditionally cultivated in the dukuh lembur. Traditionally, albizia trees have been grown with rice in the swidden cultivation and allowed to continuously grow in the secondary fallowed land. Eventually, when the fallowed land will be opened for recultivating rice, the Outer Baduy may harvest and totally cut the albizia trees and sell the logs to village middlemen to get cash income. In addition, the soil fertility of the fallowed land has been improved by planting the albizia trees. Therefore, the cultivation of cash crop of albizia trees has provided some benefits for improving soil fertility of the swidden cultivation and providing income, which eventually increases the sustainability of the Outer Baduy swidden cultivation system (Iskandar and Ellen 2000, 2007).

Unlike albizia, the coffee trees have been cultivated in the dukuh lembur instead of the swidden cultivation system (sistem huma). The practice of coffee farming is different from albizia cultivation in that it has not been appropriately mixed with rice in the swidden cultivation. Since the coffee trees have been planted mostly in the swidden system, these coffee trees have not been cut for re-cultivating the 
rice crop for further practicing of the swidden farming. Consequently, the practice of swidden system that is considered as an obligation may be disturbed by the cash cropping of coffee trees. Therefore, traditionally the coffee trees have been prohibited to be cultivated in the swidden system, and Outer Baduy people prefer to cultivate the coffee trees in the dukuh lembur.

The robusta coffee was predominantly planted by the Outer Baduy in 1980s. When the seedlings were first grown in the dukuh lembur of the Outer Baduy they were rejected because the informal leader (puun) believed that planting would promote the monoculture commercial crops, and the Outer Baduy will get involved in the commercial business instead of the simple life (hidup sederna). We argue that if the coffee trees are predominantly planted in the swidden cultivation, the practice of the swidden farming may be seriously disturbed because the coffee trees cannot be totally cut when the fallowed land will be recultivated with rice crop. Therefore, planting the robusta coffee and integrated it in the dukuh lembur have been considered to be appropriate in terms of ecological and socio-cultural aspects. Regarding the ecological aspects, the coffee trees under shade other plant canopies experience less stress than those with no shade. Litter leaves of shade trees in the coffee agroforestry systems provide additional nutrient for the soil and maintain soil humidity, particularly, during prolonged drought and when air temperature increases (Martini et al. 2017). Meanwhile, in terms of the socio-cultural aspects, since the coffee trees have predominantly been cultivated in the dukuh lembur, the trees have never been totally cut to cultivate rice of the swidden farming. Indeed, according to the Baduy tradition, the dukuh lembur has been prohibited to cut for the swidden farming.

In conclusion, the robusta coffee trees have been cultivated in the dukuh lembur of the Outer Baduy based on 'hybrid' knowledge, i.e., combination of TEK and scientific Western knowledge (cf. Iskandar and Ellen 2007). In terms of TEK, the dukuh lembur has been culturally managed for a long time by the Outer Baduy people, while the coffee farming is gradually accepted and integrated in the dukuh lembur based on the scientific knowledge or information from non-Baduy, because. Coffee crops have provided some socio-economic benefits of subsistence as well commercial economy, and may also support the sustainability of the Outer Baduy swidden cultivation as cultural identity of Baduy community.

\section{ACKNOWLEDGEMENTS}

We are grateful to the village formal leader (Jaro Pamarentah) and his staff (Carik Desa) who have given permission to conduct research in village of Kanekes, subdistrict of Leuwidamar, District of Lebak, Banten. We are also grateful to all informants of Outer Baduy for their assistant in providing various information during our field research in village of Kanekes, sub-district of Leuwidamar, Lebak, Banten. This research was supported by the Academic Leadership Grant (ALG) of Prof. Johan
Iskandar, therefore we wish to express our gratitude to the Rector of Padjadjaran University, Sumedang, Indonesia for supporting this research.

\section{REFERENCES}

Aguilar-Garavito M, Renjifo LM, Perez-Torres J. 2014. Seed dispersal by bats across four successional stages of subanden landscape. Biota Columbiana 15 (2): 87-101.

Albuquerque UP, Ramos MA, Paiva de Lucena RF, Alencar NL. 2014. Methods and techniques used to collect ethnobiological data. In: Albuquerque UP, Cruz da Cunha LVF, Paiva de Lucena RF, Alves RRN (eds.). Methods and Techniques in Ethnobiological and Ethnoecology. Humana Press, New York.

Anggarani ET. 2011. Suitability Evaluation for Coffee Plants in Bulu District, Temanggung Regency. [Thesis]. Department Geography, Faculty of Social Science, Malang State University, Malang. [Indonesian]

Aryal K, Choudhury D. 2015. Climate change: adaptation, mitigation and transformation of swidden landscapes: are we throwing the baby out with the Bathwater? In: Cairns MF (eds) Shifting Cultivation and Environmental Change: Indigenous People, Agriculture and Forest Conservation. Routledge, London.

Balgooy MMJ. 1997. Malesian Seed Plant, Vol. 1, Spot Characters. Reijkherbarium, Leiden.

Balgooy MMJ. 1998. Malesian Seed Plant, Vol. 2, Potraits of Tree Families. Reijkherbarium, Leiden.

Balgooy MMJ. 2001. Malesian Seed Plant, Vol. 3, Portrait of Non-Tree Families. Reijkherbarium, Leiden.

Berkes F, Colding J, Folke C. 2000. Rediscovery of traditional ecology as adaptive management. Ecol Appl 10 (5): 1251-1262.

Berkes F. 2008. Sacred Ecology. 2nd ed. Routledge, New York.

Bunch R. 2015. Learning from migratory agriculture around the world: to improve both swidden and modern agriculture in Southeast Asia. In: Cairns MF (eds) Shifting Cultivation and Environmental Change: Indigenous People, Agriculture and Forest Conservation. Routledge, London.

Ellen R, Harris H. 2000. Introduction. In: Ellen R, Parkes P, Bicker A (eds) Indigenous Environmental Knowledge and Its Transformation. Harwood, Amsterdam.

Elson RE. 1994. Village Java Under Cultivation System 1830-1870. Allen and Unwin, Sydney.

Erni C. 2006. From opportunism to resource management: adaptation and the emergence of environmental conservation among indigenous swidden cultivators on Mindoro Island, Philippines. Conserv Soc 4 (1): 102-131.

Franco FM. 2015. Calendars and ecosystem management: some observations. Human Ecol. DOI 10.1007/s10745-015-9740-6.

Garrity DP. 2015. Learning to cope with rapid change: evergreen agriculture transformations and insights between Africa and Asia. In: Cairns MF (eds) Shifting Cultivation and Environmental Change: Indigenous People, Agriculture and Forest Conservation. Routledge, London.

Geertz C. 1963. Agricultural Involution: The Process of Ecological Change in Indonesia. University of California, Berkeley.

Granoveter M. 1985. Economic action and social structure: the problem of embeddedness. Am J Sociol 91 (3): 481-510.

Heyne K. 1987. Useful Plant in Indonesia. Badan Litbang Kehutanan, Jakarta. [Indonesian].

Hulupi R, Martini E. 2013. Guidelines for Cultivation and Maintenance of Coffee Plants in Mixed Garden. World Agroforestry Center (ICRAF), Bogor. [Indonesian].

Iskandar BS, Iskandar BS, Partasasmita R, Alfian RL. 2018c. Planting coffee and take care of forest: a case study on coffee cultivation in forest carried out among people of Palintang, highland of Bandung, West Java, Indonesia. Biodiversitas 19 (6): 2183-2195.

Iskandar BS, Iskandar J, Partasasmita R. 2018a. Site selection and soil fertility management by other Baduy people (Banten, Indonesia) in maintaining swidden cultivation productivity. Biodiversitas 19 (4): 1334-1346.

Iskandar BS, Iskandar J, Partasasmita R. 2018b. Strategy of the Outer Baduy community of South Banten (Indonesia) to sustain their 
swidden farming traditions by temporary migration to non-Baduy areas. Biodiversitas 19 (2): 453-464.

Iskandar J, Ellen R. 1999. In situ conservation of rice landraces among the Baduy of West Java. J Ethnobiol 19 (1): 97-125.

Iskandar J, Ellen R. 2000. The contribution of Paraserianthes (Albizia) falcataria to sustainable swidden management among the Baduy of West Java. Human Ecol 28 (1):1-17.

Iskandar J, Ellen R. 2007. Innovation, 'hybrid' knowledge and the conservation of relict rainforest in upland Banten. In Ellen R (eds) Modern Crises and Traditional Strategies: Local Ecological Knowledge in Island Southeast Asia. Berghahn Books, New York.

Iskandar J, Iskandar BS. 2016. Ethnoastronomy-the Baduy agricultural calendar and prediction of environmental perturbations. Biodiversitas 17 (2): 694-703.

Iskandar J, Iskandar BS. 2017. Various plants of the traditional rituals: ethnobotanical research among Baduy community. Biosaintifica 9 (1): 114-125.

Iskandar J, Iskandar BS. 2018. Strategy of the Outer Baduy community of South Banten (Indonesia) to sustain their swidden farming traditions by temporary migration to non-Baduy areas. Biodiversitas 19 (2): 453-464.

Iskandar J. 1998. Swidden Cultivation as a Form of Cultural Identity: The Baduy Case. [Dissertation]. University of Kent at Canterbury, UK.

Iskandar J. 2007. Responses to environmental stress in the Baduy swidden system, South Banten, Java. In: Ellen R (eds) Modern crises and Traditional Strategies: Local Ecological Knowledge in Island Southeast Asia. Berghahn Books, New York.

Iskandar J. 2018. Ethnobiology, Ethnoecology and Sustainable Development. Plantaxia, Yogyakarta. [Indonesian].

Khattri MB. 2003. Agricultural and ritual landscape: a case study from the Magars of Argal, Baglung District, Nepal. Social Anthropol 8: 88104.

Lasmiyati 2015. Coffee in Priangan in $18^{\text {th }}-19^{\text {th }}$ Century. Patanjala 7 (2): 217-232. [Indonesian]

Lovelace GW. 1984. Cultural beliefs and the management of agroecosystems. In: Rambo AT, Sjaise PE (eds) An Introduction to Human Ecology Research on Agricultural Systems in Southeast Asia. East-West Center, Honolulu, Hawaii.

Martini E, Riyandoko, Roshetko. 2017. Guidelines for Establishing Coffee-Agroforestry Systems. World Agroforestry Centre (ICRAF), Bogor.
Mashman V, Nayoi P. 2015. The Bidayuh of Sarawak: gender, spirituality and swiddens. In: Cairns MF (eds) Shifting Cultivation and Environmental Change: Indigenous People, Agriculture and Forest Conservation. Routledge, London.

Newing H, Eagle CM, Puri RK, Watson CW. 2011. Conducting Research in Conservation: A Social Science Perspective. Routledge, London.

Orlove B, Roncoli C, Kabugo M, Majugu A. 2010. Indigenous climate knowledge in southern Uganda: the multiple components of a dynamic regional system. Clim Change 100: 243-265.

Plattner S. 1989. Introduction. In: Plattner S (ed.). Economic Anthropology. Standford University Press, Standford, USA.

Prasetyo PN, Noerfahmy, Tata HL. 2011. Typical Bat Species of Sumatran Agroforest. World Agroforest, Bogor [Indonesian]

Raintree J, Warner K. 2015. Agroforestry Pathways Revisited: Voices from the past. In: Cairns MF (eds) Shifting Cultivation and Environmental Change: Indigenous People, Agriculture and Forest Conservation. Routledge, London.

Ramakrishnan PS. 2015. Shifting Agriculture and Fallow Management Options: Where do we stand? In: Cairns MF (eds) Shifting Cultivation and Environmental Change: Indigenous People, Agriculture and Forest Conservation. Routledge, London.

Reijentjes C, Haverkort B, Waters-Bayer. 1992. Farming for the Future: An Introduction to Low-External-Inputs and Sustainable Agriculture. The MacMillan Press, Ltd., New York.

Subandi HM. 2011. Cultivation Plant Plantation (Part of coffee Plant). Gunung Djati Press, Bandung. [Indonesian]

Sulistyawati E. 2011. The historical demography of resource use in a swidden community in West Kalimantan. In: Dove MR, Sajise PE, Doolittle A (eds.). Beyond The Sacred Forest: Complicating Conservation in Southeast Asia. Duke University Press, Durham.

Suyanto A. 2001. Indonesian Bats. Center and Development of BiologyLIPI. Herbarium Bogoriense, Bogor. [Indonesian]

Widianingsih Y. 2006. Contribution of Management of Coffee Under Standing in the PHBM Program for Household Income in BKPH of Pulosari Village, Pangalengan, KPH of South Bandung. [Undergraduate Thesis]. Department of Forest Management, Faculty of Forestry, Bogor Agricultural University, Bogor. [Indonesian]

Wordley C, Altringham J, Raman TRS. 2014. Commentary: bats in Indian coffee plantations: doing more good than harm? Curr Sci 1017 (12): 1958-1960.

Zakaria MM. 2009. Priangan coffee in the nineteenth century. History: Intl J History Edu 10 (2): 131-150. 